\title{
STUDI PEMBUATAN SELAI CAMPURAN TIMUN SURI (Cucumis lativus) DAN BUAH NAGA (Hylocereus Polyrhizus)
}

\author{
Imera Lipta Merda ${ }^{(1)}$, dan Rifni Novitasari, S.Tp., MP(2) \\ (1) Alumni Teknologi Pangan Faperta UNISI

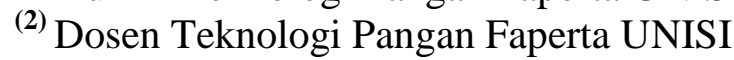

\begin{abstract}
Abstrak
Selai merupakan produk makanan yang memiliki tekstur kental yang dapat diolah dari berbagai macam buah dan pada umumnya selai dapat berbentuk padat maupun semi padat buah-buahan yang dipilih untuk dijadikan dalam pembuatan yaitu buah yang telah matang, seperti Timun Suri dan buah Naga yang meiliki warna yang pekat. Tanaman timun Suri dengan nama ilmiahnya adalah Cucumis lativus sudah banyak dikenal dan dikonsumsi masyarakat, Timun suri bisa ditanam kapan saja dan tidak mengenal musim dan juga banyak terdapat pada Kabupaten Indragiri Hilir dengan memiliki rasa yang ciri khas manis dan langu. Buah timun Suri memiliki kandungan mineral yang cukup tinggi, kandungan dalam $100 \mathrm{~g}$ buah suri terdiri dari $1.008 \mathrm{mg}$ kalium, $768 \mathrm{mg}$ kalsium dan $422 \mathrm{mg}$ fosfor (Hayati et all., 2008), sedangkan Buah Naga (Hylocereus polyrhizus) daging merah yaitu buah yang rendah kolestrol dan kaya akan vitamin C, E, asam lemak tidak jenuh tunggal, dan serat yang dapat membantu fungsi dari antioksidan. Dari penggabungan dua jenis buah tersebut menjadi selai maka dilakukan penelitian dengan menggunakan metode rancangan acak lengkap ( $\mathrm{RAl}$ ), dengan empat perlakuan dan tiga kali ulangan yang mencapai hasil yang terbaik yaitu pada perlakuan D dengan perbandingan buah naga dan timun suri (100 g buah naga : $150 \mathrm{~g}$ timun suri) dengan hasil nilai pada analisa kimia yaitu kadar Air 13,00\%, kadar Gula 59,00\%, Vitamin C $0,69 \%$, sedangkan pada analisa organoleptik yaitu warna $3,65 \%$, aroma $3,50 \%$, rasa $3,90 \%$, dan tekstur $3,55 \%$.
\end{abstract}

Kata Kunci: Selai, Timun Suri, Buah Naga

\section{PENDAHULUAN}

Tanaman timun Suri dengan nama ilmiahnya adalah Cucumis lativus saat ini sudah banyak dikenal dan dikonsumsi masyarakat, timun suri bisa ditanam kapan saja dan tidak mengenal musim dan juga banyak terdapat pada Kabupaten Indragiri Hilir dengan memiliki rasa yang ciri khas manis dan langu, dan juga harganya yang terjangkau atau murah.Timun Suri meski tawar namun berasa segar dan kaya akan kandungan mineral yang bermanfaat untuk tubuh.

Buah timun Suri memiliki kandungan mineral yang cukup tinggi, kandungan dalam $100 \mathrm{~g}$ buah suri terdiri dari $1.008 \mathrm{mg}$ kalium, $768 \mathrm{mg}$ kalsium dan $422 \mathrm{mg}$ fosfor (Hayati et al., 2008). Kalsium berfungsi untuk menjaga keseimbangan air dalam tubuh, kesehatan jantung, menurunkan tekanan darah, dan membantu pengiriman oksigen ke otak (Pramita, 2003).Tetapi timun suri ini memiliki warna daging 
buahnya yang pucat sehingga tidak menarik dalam uji Organoleptik dan dibuat jadi produk olahan. Untuk itu didalam pengolahan perlu dicari alternative seperti perlakuan dengan penambahan produk lain seperti buah naga yang memiliki daging buah berwarna merah dan juga dapat mempengaruhi nilai gizi produk.

Buah Naga (Hylocereus polyrhizus) daging merah yaitu buah yang mirip dengan buah nanas ini hanya saja memiliki sulur disekujur kulitnya dan daging buahnya berwarna merah, Buah Naga mengandung pektin yang mampu mengentalkan secara alami dan mengandung fitoalbumin yang kemampuan antioksidannya sangat tinggi.Antioksidan pada buah naga ini bisa mencegah terbentuknya radikal bebas penyebab kanker. Selain itu buah naga rendah kolestrol dan kaya akan vitamin $\mathrm{C}$, $\mathrm{E}$, asam lemak tidak jenuh tunggal, dan serat yang dapat membantu fungsi dari antioksidan (Herawati, 2013).Dan juga kandungan mineral yang tinggi baik untuk kesehatan tubuh Buah Naga banyak terdapat dimana saja dan selalu tersedia sepanjang waktu karena buah naga bukan termasuk buah musiman.Tetapi harga Buah Naga cukup mahal,warnanya yang pekat dan sari buahnya terlalu kental bahkan boleh dikatakan tidak berair sehingga juga sulit jika djadikan produk olahan.

Dari uraian tersebut dengan melihat dari kelebihan dan kekurangan dua jenis buah diatas maka timbulah pemikiran untuk menggabugkan dua buah tersebut menjadi suatu bentuk produk olahan yang memiliki nilai yang tinggi yaitu Selai. Selai merupakan produk makanan yang memiliki tekstur kental yang dapat diolah dari berbagai macam buah dan pada umumnya selai dapat berbentuk padat maupun semi padat buah-buahan yang dipilih untuk dijadikan dalam pembuatan selai adalah buah yang sudah matang.Syarat pembuatan selai yaitu Pektin merupakan koloidal yang bermuatan negatif, penambahan gula dapat mempengaruhi keseimbangan pektin, pektin akan menggumpal dan membentuk serabut halus yang mampu menahan cairan, berdasarkan sifat inilah dimanfaatkan dalam pembuatan selai.

Buah timun suri merupakan buah yang jarang dijadikan produk olahan bagi masyarakat karena timun suri tidak memiliki warna yang cerah padahal timun suri memiliki kandungan gizi yang baik untuk kesehatan, sedangkan buah naga memiliki warna buah yang cerah (merah keungu-unguan) dan juga meiliki kandungan gizi yang baik untuk kesehatan dari penelitian sebelumnya yang dilakukan oleh Fachruddin, (2008) dalam pembuatan selai hanya buah naganya saja yang belum diverivikasi dari permasalahan diatas dengan hal ini penulis memiliki pemikiran untuk menggabungkan dua jenis buah timun Suri dan buah Naga dalam produk olahan selai dan melakukan penelitian dengan judul "Studi pembuatan selai campuran Timun Suri (cucumis Lativus) dan Buah Naga (Hylocereus polyrhizus)",

Selai merupakan makanan yang dapat dikonsumsi oleh semua kalangan usia dan dalam penelitian ini selai tidak menggunakan banyak bahan tambah hanya menggunakan bahan tambah gula pasir, dan penulis telah melakukan penelitian pendahuluan dimana selai terdapat 4 perlakuan yaitu $\mathrm{PA}=(25 \mathrm{~g}$ Buah naga : $225 \mathrm{~g}$ Timun Suri), PB = (50 g Buah naga : $200 \mathrm{~g}$ Timun Suri), $\mathrm{PC}=(75 \mathrm{~g}$ Buah naga $: 175 \mathrm{~g}$ Timun Suri $), P D=(100 \mathrm{~g}$ Buah naga $: 150 \mathrm{~g}$ Timun Suri).

Tujuan dari penelitian ini adalah untuk mengetahui perbandingan Sari 
Buah Timun Suri dan sari buah Naga yang tepat dalam pengolahan selai sehingga menghasilkan selai campuran Timun Suri dan Buah Naga baik dari segi kualitas Analisa dan secara Organoleptik.

Adapun manfaat dari penelitian ini adalah sebagai sumber informasi kepada masyarakat luas mengenai proses pembuatan selai kombinasi timun suri dan buah naga dan Memberikan informasi bahwa timun suri dapat diolah menjadi produk baru yang berkualitas dan memiliki kandungan gizi yang baik.

\section{METODE PENELITIAN}

\section{Bahan}

Bahan utama yang dipergunakan pada penelitian ini adalah Buah Timun Suri yang masih segar dan sudah agak tua dagingnya berwarna oren muda,Buah Naga yang berdaging merah yang masih segar, dan gula pasir.

Bahan yang digunakan untuk analisa kimia yaitu larutan tembaga sulfat,larutan tartrat basa,larutan fehling dengan modifikasi soxhlet,larutan dekstrosa standar,larutan metilenbiru $0.2 \%$ dalam air,asam Metafosfat $\left(\mathrm{HPO}_{3}\right)$ 3\%:Larutan $\mathrm{HPO}_{3}$ batang/pellet didalam akuades,Asam askorbat standar,larutan dye.

\section{Alat}

Peralatan yang digunakan untuk pembuatan selai yaitu juicer, kompor, wadah, pisau, panci, sendok pengaduk. Peralatan yang digunakan untuk analisis kimia adalah oven dengan kisaran suhu $105^{\circ} \mathrm{C}$ dan $100^{\circ}-102^{\circ}$, cawan beserta tutupnya, desikator, penjepit cawan dan timbangan analitik, Erlenmeyer $125 \mathrm{ml}$, $50 \mathrm{ml}$, gelas ukur,hot plate, buret, labu ukur $100 \mathrm{ml}$, penangasair, kertas saring, mikroburet, pipet ukur $10 \mathrm{ml}$, blender.

\section{Metode Penelitian}

Metode penelitian ini menggunakan Rancangan Acak Lengkap (RAL) dengan Studi perbandingan Buah Timun Suri dengan Buah Naga didalam pengolahan Selai dengan 4 perlakuan dan 3 ulangan denga total bahan 250 gram.

$\mathrm{PA}=(25$ g Buah naga : $225 \mathrm{~g}$ Timun Suri $)$

$\mathrm{PB}=(50 \mathrm{~g}$ Buah naga $: 200 \mathrm{~g}$ Timun Suri $)$

$\mathrm{PC}=(75$ g Buah naga : $175 \mathrm{~g}$ Timun Suri $)$

$\mathrm{PD}=(100 \mathrm{~g}$ Buah naga $: 150 \mathrm{~g}$ Timun Suri $)$

\section{Pelaksanaan Penelitian}

Proses pembuatan selai campuran timun suri dan buah naga terdiri dari tiga tahap yaitu:

\section{Proses Pembuatan Sari Buah Timun Suri}

1. Sortasi

Sortasi dilakukan untuk memilih Buah Timun suri yang bagus, tanpa ada yang cacat,daging buahnya yang sudah agak tua dan matang.

2. Pencucian

Pencucian timun suri dilakukan dengan air yang mengalir bertujuan untik menghilangkan kotoran

3. Pengupasan

Pengupasan kulit buah timun suri sebelum dilakukan pemotongan dan biji Timun suri dipisah dari dagingnya.

4. Pemotongan

Pemotongan buah timun suri menjadi bagian-bagian kecil dengan tujuan untuk mempermudah saat dijuicer. Pemotongan menggunakan pisau yang tajam.

\section{Penghancuran}

Penghancuran buah timun suri dengan menggunakan juicer. 


\section{Pemisahan}

Pemisahan sari buah timun suri dari ampasnya.

\section{Proses Pembuatan Sari Buah Naga beracuan pada, (Fatonah, 2002)}

\section{Sortasi}

Sortasi dilakukan untuk memilih buah naga yang bagus, tanpa ada yang cacat,daging buahnya yang berwarna merah dan matang.

2. Pencucian

Pencucian buah naga dilakukan dengan air yang mengalir bertujuan untik menghilangkan kotoran

3. Pengupasan

Pengupasan kulit buah naga sebelum dilakukan pemotongan

4. Pemotongan

Pemotongan buah naga menjadi bagian-bagian kecil dengan tujuan untuk mempermudah saat dijuicer. Pemotongan menggunakan pisau yang tajam.

5. Penghancuran

Penghancuran buah naga dengan menggunakan juicer.
6. Pemisahan

Pemisahan sari buah naga dari ampasnya setelah dilakukan penjuiceran.

Proses pembuatan selai campuran, beracuan pada (Fachruddin, 2008).

1. Persiapan Bahan

Persiapan bahan yaitu sari buah timun suri dan buah naga yang telah dibuat.

2. Pencampuran

Pencampuran sari buah timun suri, sari buah naga,dan sukrosa sebelum dimasak sesuai dengan perlakuan.

3. Pemasakan

Pemasakan selai campuran selama 15 menit di atas api kecil dengan suhu berkisar $70^{\circ} \mathrm{C}$ sesuai dengan prapenelitian yang telah dilakukan.

\section{HASIL DAN PEMBAHASAN}

\section{Kadar Air}

Hasil sidik ragam dari perlakuan perbandingan dari pembuatan selai campuran menunjukan bahwa kadar air berbeda nyata. Pengaruh pencampuran buah naga dan timun suri terhadap kadar air selai yang dihasilkan setelah uji lanjut dapat dilihat pada tabel 1 .

Tabel 1. Rata-rata hasil analisa kadar air selai dengan pencampuran buah naga dan timun suri

\begin{tabular}{|l|c|}
\hline Perlakuan & Rata-rata(\%) \\
\hline A $(25 \mathrm{~g}$ buah naga $: 225 \mathrm{~g}$ timun suri $)$ & $11,33 \mathrm{a}$ \\
\hline $\mathrm{B}(50 \mathrm{~g}$ buah naga $: 200 \mathrm{~g}$ timun suri $)$ & $12,33 \mathrm{a}$ \\
\hline C $(75 \mathrm{~g}$ buah naga $: 175 \mathrm{~g}$ timun suri $)$ & $13,00 \mathrm{a} \mathrm{b}$ \\
\hline D $(100 \mathrm{~g}$ buah naga $: 150 \mathrm{~g}$ timun suri $)$ & $13,00 \mathrm{~b}$ \\
\hline
\end{tabular}

Keterangan : Angka-angka pada jalur yang sama diikuti oleh huruf kecil yang sama menunjukan berbeda tidak sangat nyata menurut Uji Beda Nyata Terkecil taraf 5\% atau $1 \%$.

Hasil analisa kadar air menunjukan bahwa jumlah kadar air tertinggi terdapat pada perlakuan D (100 g buah naga : 150 g timun suri) yaitu sebesar $13,00 \%$ dan kadar air terendah terdapat pada perlakuan A (25 g buah : $225 \mathrm{~g}$ timun suri) yaitu sebesar $11,33 \%$. Rendahnya kadar air pada perlakuan A dikarenakan 
dalam perlakuan ini sedikitnya pencampuaran buah naga, perlakuan A hanya menggunakan sebanyak $25 \mathrm{~g}$ buah naga dan 225 timun suri, selain kurangnya buah Naga proses pemasakan selai juga menjadi salah satu faktor rendahnya kadar air, hal ini sesuai dengan pendapat (Sidauruk, 2013), Menurut Nurhayati et all. (2014) bahwa proses pengolahan menjadi selai menyebabkan terjadinya pengurangan kadar air secara nyata dari kadar air buah naga segarnya yang diakibatkan adanya penguapan air selama pemanasan. Penguapan air dan proses pemanasan pada produk pangan semi basah Intermediet Moisture Food (IMF) dapat menyebabkan perubahan baik fisik kimia maupun fungsionalnya.

Pada perlakuan D (100 g buah naga : $150 \mathrm{~g}$ timun suri) yaitu dengan jumlah skor sebesar $13,00 \%$ hal ini disebabkan karena buah timun suri memiliki kandungan kadar air yang tinggi yaitu 96,32 g (Nirmala, 2008), dan apabila ditambahkan lagi dengan buah Naga sebesar $100 \mathrm{~g}$ maka produk yang dihasilkan akan lebih tinggi kadar airnya hal ini sesuai dengan pernyataan (Panjuantiningrun, 2009) bahwa buah Naga juga memiliki kandungan kadar air yang tinggi yaitu sebesar 82,5-83 g. dan didukung oleh Rekna (2012) bahwa buah naga tinggi akan kandungan airnya sehingga semakin banyak buah naga yang ditambahkan maka semakin tinggi kadar air yang dihasilkan.

\section{Analisa Kadar Gula Reduksi}

Hasil sidik ragam dari perlakuan perbandingan pencampuran buah naga dan timun suri dalam pembuatan selai menunjukan bahwa kadar gula $\mathrm{F}$ hitung $<\mathrm{F}$ tabel pada taraf $5 \%$ berbeda tidak nyata terhadap kadar gula, pengaruh pencampuran buah naga dan timun suri terhadap kadar gula selai yang dihasilkan setelah uji lanjut dapat dilihat pada tabel 2 .

Tabel 2. Rata-rata hasil analisa kadar gula reduksi selai dengan pencampuran buah naga dan timun suri

\begin{tabular}{|l|c|}
\hline \multicolumn{1}{|c|}{ Perlakuan } & Rata-rata(\%) \\
\hline $\mathrm{D}(100 \mathrm{~g}$ buah naga $: 150 \mathrm{~g}$ timun suri $)$ & $59,00 \mathrm{a}$ \\
\hline $\mathrm{C}(75 \mathrm{~g}$ buah naga $: 175 \mathrm{~g}$ timun suri $)$ & $59,33 \mathrm{a} \mathrm{b}$ \\
\hline B (50 g buah naga $: 200 \mathrm{~g}$ timun suri $)$ & $64,00 \mathrm{~b}$ \\
\hline A $(25 \mathrm{~g}$ buah naga $: 225 \mathrm{~g}$ timun suri $)$ & $64,0 \quad \mathrm{~b}$ \\
\hline
\end{tabular}

Keterangan : Angka-angka pada jalur yang sama diikuti oleh huruf kecil yang sama menunjukan berbeda tidak sangat nyata menurut Uji Beda Nyata Terkecil taraf 5\% atau $1 \%$.

Hasil analisa kadar gula reduksi menunjukan bahwa jumlah kadar gula tertinggi terdapat pada perlakuan A $(25 \mathrm{~g}$ buah naga : $225 \mathrm{~g}$ timun suri) yaitu sebesar $64,00 \%$ dan kadar gula terendah pada perlakuan D (100 g buah naga : 150 g timun suri) yaitu sebesar $59,00 \%$. Hal ini disebabkan pada perlakuan A tersebut Timun suri memiliki kandungan air yang tinggi sehingga akan lebih mudah diikat oleh gula sesuai pernyataan Muchtadi
(1997) bahwa gula memiliki kemampuan untuk mengikar air, penambahan gula juga berpengaruh pada kekentalan gel yang terbentuk, gula akan menurunkan kekentalan menurut Winarno (1997) adanya gula akan menyebabkan gel lebih tahan terhadap kerusakan mekanik.

Gula yang ditambahkan dapat mengikat air bebas dan memperpanjang umur simpan selai namun konsentrasi gula yang tinggi dalam larutan akan 
menurunkan derajat gelatinisasi pati, kekentalan dan kekuatan gelnya (Fennema, 1995).

\section{Analisa Vitamin C}

Hasil sidik ragam dari perlakuan perbandingan pencampuran buah naga dan timun suri dalam pembuatan selai menunjukan bahwa analisa Vitamin c F hitung < $\mathrm{F}$ tabel pada taraf 5\% berbeda tidak nyata terhadap vitamin $\mathrm{C}$ (lampiran 6), pengaruh pencampuran buah naga dan timun suri terhadap vitamin $\mathrm{C}$ selai yang dihasilkan setelah uji lanjut dapat dilihat pada tabel 3 .

Tabel 3. Rata-rata Hasil Analisa Vitamin C Selai dengan Pencampuran Buah Naga dan Timun Suri

\begin{tabular}{|l|c|}
\hline \multicolumn{1}{|c|}{ Perlakuan } & Rata-rata(\%) \\
\hline A ( $25 \mathrm{~g}$ buah naga $: 225 \mathrm{~g}$ timun suri $)$ & 0,61 \\
\hline $\mathrm{B}($ 50 g buah naga $: 200 \mathrm{~g}$ timun suri $)$ & 0,64 \\
\hline $\mathrm{C}($ 75 g buah naga $: 175 \mathrm{~g}$ timun suri $)$ & 0,65 \\
\hline D (100 g buah naga $: 150 \mathrm{~g}$ timun suri $)$ & 0,69 \\
\hline
\end{tabular}

Keterangan : Angka-angka pada jalur yang sama diikuti oleh huruf kecilyang sama menunjukan berbeda tidak nyata menurut Uji Beda Nyata Terkecil taraf 5\% atau $1 \%$.

Hasil analisa vitamin C menunjukan bahwa jumlah uji yang tertinggi terdapat pada perlakuan D (100 $\mathrm{g}$ buah naga : $150 \mathrm{~g}$ timun suri) yaitu dengan nilai $0,69 \%$ hal ini dikarenakan bahwa dimana pencampuran buah naga dengan jumlah yang lebih besar sesuai dengan Taiwan Food Industry Develop \& Research Authoritis (2005) kandungan Vitamin $\mathrm{C}$ pada buah naga yaitu 8-9 g dibandingkan pada timun suri hanya terdapat $24,86 \mathrm{mg}$ Vitamin C didalamnya. (laporan Penelitian Program PHK A2, 2008) semakin banyak pencampuran buah Naga maka akan semakin tinggi kandungan Vitamin $\mathrm{C}$ didalamnya.

Menurut Winarno (1991), Vitamin C merupakan vitamin yang paling mudah rusak dibandingkan dengan jenis vitamin lainnya. Disamping sangat larut dalam air ,vitamin $\mathrm{C}$ mudah teroksidasi dan proses tersebut dipercepat oleh panas, sinar, alkali, enzim,, dan oksidator lainnya. Oleh sebab itu kandungan Vitamin $\mathrm{C}$ yang terdapat pada selai campuran tidak menutup kemungkinan akan mengalami penurunan ketika telah diolah menjadi selaii diakibatkan olehnrusaknya vitamin $\mathrm{C}$ oleh proses pengolahan.

Semakin banyak suatu bahan pangan melalui proses pengolahan, maka akan berkurang nilai gizi atau vitamin yang terdapat dalam buah tersebut. Vitamin $\mathrm{C}$ merupakan sumber antioksidan yang member manfaat bagi tubuh antara lain membantu menjaga kesehatan sel dan memperbaiki kekebalan tubuh. (Kumalaningsih dan Suprayogi, 2006).

\section{Penilaian Organoleptik}

\section{Warna}

Uji organoleptik terhadap warna selai campuran berkisar 3,35 \% - 3,65\% Nilai terendah terdapat pada perlakuan A (25 g buah naga : $225 \mathrm{~g}$ timun suri) sebesar 3,35 \% dan tertinggi pada perlakuan D (100 g buah naga : $150 \mathrm{~g}$ timun suri) sebesar 3,65\%.

Warna merah keungu-unguan pada selai berasal dari buah naga, pada setiap perlakuan semakin besar jumlah buah naga yang dicampurkan maka akan 
menghasilkan warna selai yang cerah, sesuai dengan pernyataan (Fajriani, 2013) bahwa warna dari buah naga berasal dari pigmen baik yang ada pada kulitnya maupun didalam buahnya. Pigmen tersebut adalah pigmen betalain yang mengandung nitrogen, semakin tinggi kandungan nitrogennya maka warna merah pada buah naga akan semakin pekat.

Penentuan mutu suatu pangan pada umumnya tergantung pada warna, karena warna tampilan terlebih dahulu (Winarno 2004). secara visual faktor warna sangat menentukan mutu. warna juga dapat menarik perhatian para konsumen sehingga dapat menilai atau memberi kesan suka atau tidak suka. Secara visual, faktor warna sangat menentukan tingkat kesukaan konsumen terhadap produk.

\section{Aroma}

Penilaian panelis terhadap aroma selai menunjukkan bahwa selai dari keempat perlakuan mempunyai nilai yang hampir sama dimana nilai organoleptik aroma berkisar 3,45\% $3,70 \%$. Nilai tertinggi terdapat pada perlakuan A (25 g buah naga : $225 \mathrm{~g}$ timun suri) yaitu dengan nilai 3,70\% dan nilai terendah terdapat pada perlakuan C (75 g buah naga : $175 \mathrm{~g}$ timun suri) yaitu dengan nilai 3,45 . Hasil analisa sidik ragam menunjukkan bahwa respon panelis terhadap aroma selai campuran timun suri dan buah naga yang dihasilkan tidak berbeda nyata. Tingginya skor pada perlakuan A hal ini disebabkan karena tingginyanya jumlah timun suri yang terdapat dalam perlakuan tersebut sesuai dengan pernyataan (Padmiarso, 2012) Selain vitamin, mineral esensial seperti kalsium,fosfor dan besi juga banyak terdapat didalam timun suri, Aroma yang khas pada timun suri memberikan kesegaran. Sehingga semakin banyak pencampuran Timun Suri pada selai maka akan keluar aroma khas timun suri pada selai yang dihasilkan.

Bau makanan banyak menentukan kelezatan bahan makanan tersebut,dalam hal bau lebih banyak sangkut-pautnya dengan alat panca indra penghidung, bau-bauan baru dapat dikenali bila berbentuk uap, dan molekul-molekul komponen bau tersebut harus sempat menyentu silia sel olfaktori (Winarno 1992).

\section{Rasa}

Uji organoleptik terhadap rasa selai campuran berkisar 3,55\% - 3,90\% nilai tertinggi terdapat pada perlakuan D (100 g buah naga : $150 \mathrm{~g}$ timun suri) yaitu dengan nilai $3,90 \%$ hal ini dikarenakan pencampuran buah naga dalam jumlah yang besar sehingga menghasilkan rasa yang disukai oleh para panelis sesuai dengan pernyataan (Cahyono, 2009) bahwa buah naga memiliki rasa yang manis seperti buah kiwi sehingga banyak disukai dan ditambah lagi oleh rasa dari timun Suri(Hayati et al., 2008), Buah timun Suri memiliki daging yang tebal, jenis dan rasa khas yang segar,sehingga selai yang dihasilkan memiliki rasa yang segar.

Bahan pangan tidak hanya terdiri dari satu rasa saja akan tetapi gabungan dari berbagai mcam rasa yang terpadu sehingga menimbulkan cita rasa makanan yang utuh. Menurut Winarno (2004) rasa dipengaruhi oleh beberapa faktor yaitu senyawa kimia, suhu, konsentrasi dan interaksi dengan komponen rasa lain yaitu komponen rasa primer. Rasa juga merupakan salah satu factor dalam pengujian organoleptik, rasa lebih banyak melibatkan indra lidah(perasa). Rasa yang enak dapat menarik perhatian konsumen sehingga 
konsumen lebih cenderung menyukai makanan dari rasanya.

\section{Tesktur}

Penilaian panelis terhadap tekstur selai berkisar antara 2,95\% - 3,55\%, perlakuan B, C, D berbeda nyata dengan perlakuan A hal ini disebabkan karena pada perlakuan A tersebut persentase Timun suri dalam jumlah yang besar yaitu A (25 g buah naga : $225 \mathrm{~g}$ timun suri) dengan nilai $2,95 \%$, sesuai dengan pendapat (Nirmala, 2008) bahwa timun suri memiliki kandungan kadar air yang tinggi yaitu 96,32 g sehingga semakin tinggi timun Suri yang dicampurkan semakin tinggi kadar airnya maka semakin akan berpengaruh terhadap tekstur yang dihasilkan.

Tekstur produk tergantung pada kekompokan pratikel penyusunannya bila produk tersebut dipatahkan sedaangkan mutu teksturnya ditentukan oleh kemudahan perpecahannya pratikelpratikel penyusunannya bila produk tersebut dikunyah,serta sifat-sifat pratikel yang dihasilkan penilaian tekstur suatu bahan melalui mulut dapat dirasakan ketika bahan dipatah atau dikunyah dan ditelan, (Almusawa M 2013).

\section{KESIMPULAN DAN SARAN}

\section{Kesimpulan}

Kesimpulan yang dapat diperoleh setelah melakukan penelitian ini ialah hasil terbaik pada selai campuran yang dihasilkan yaitu terdapat pada perlakuan $\mathrm{D}$ dengan perbandingan buah naga dan timun suri (100 g buah naga : $150 \mathrm{~g}$ timun suri) dengan hasil nilai pada analisa kimia yaitu kadar Air 13,00\%, kadar Gula 59,00\%, Vitamin C 0,69\%, sedangkan pada analisa organoleptik yaitu warna $3,65 \%$, aroma $3,50 \%$, rasa $3,90 \%$, dan tekstur $3,55 \%$.

\section{Saran}

Untuk penelitian selanjutnya diharapkan dapat memperhatikan faktor pencampuran buah naga dan timun suri pada selaiseperti suhu pemasakan dan lama pengadukan serta waktu yang digunakan saat proses pengolahan.

\section{DAFTAR PUSTAKA}

AOAC Assosiation of Official Analytical Chermist, 2005. Official Method of Analysis of the assosiation of Official Analytial of Chermist.Arlington : The Assosiation of Official Analytical Chermist, inc.

Almusawa M. 2013. Penelitian sensori pangan mempelajari tekstur makanan. [jurnal] program studiteknologi industry pangan. Fakultas industry pertanian

Arta, D. 2009. Inilah khasiat istimewa dibalik Buah Naga.http://lifestyle.okezone .com.

Astawan, M. 2008. Manfaat Mentimun, Tomat dan The. Gaya Hidup sehat. Terbang: Jakarta

Astuti N. 2016. Studi Perbandingan Labu Siam(Sechium Edule Sw) Dan Rumput Laut (Euchema Cottonii) Terhadap Mutu Permen Jelly. Fakultas Pe rtanian. Universitas Islam Indragiri.

Cahyono, Bambang. 2009. Sukses Bertanam Buah Naga. Jakarta. Pustaka Min.

Fachruddin, L. 2008. Membuat aneka Selai, Yogjakarta.

Fatonah, W. 2002. Optimasi Selai dengan Bahan Baku Ubi Jalar Cilembu. Naskah Skripsi S-I. Fakultas Teknologi Pertanian. Institut Pertanian Bogor, Bogor.

Faridah A, 2008. Patiseri Jilid 3. Jenderal Manajemen Pendidikan 
dasar dan Menengah, Departemen Pendidikan Nasional, Jakarta.

Herawati N. 2013. Formulasi Ekstrak

Kulit Buah Naga

Merah(Hylocereus

polyhizus), Rosella dan buah Salam pada pembuatan Minuman Alami. Belum Diplublikasikan. Jember: Fakultas Teknologi Pertanian Universitas Jember.

Hayati, A, Lidiasa, E, dan parwiyanti, 2008.Karakteristik timun suri. Laporan penenlitian program PHK A2. Universitas Sriwijaya, Indralaya.

Kumalaningsih, S., Suprayogi, dan B. Yuda. 2006. Teknologi Pangan. Membuat makanan siap saji.Trubus Agrisarana 2006 : Surabaya.

Meilisa R. 2015. Pengaruh Perbandingan Gula Pasir (sukrosa) dengan Gula Merah (Gula Aren) Terhadap Karakteristik Noga Kacang Hijau (Phaseolus Radiatus L).Fakultas Teknik Universitas Pasundan Bandung.

Muchtadi, T.R dan Sugiyono. 1997. Ilmu Pengetahuan Bahan Pangan. Pusat Antar Universitas Pangan dan Gizi, IPB. Bogor.

Nirmala, M. 2008. Mentimun Si "Dingin" dengan 1001 Manfaat. Retrieved from http://cybermed.cbn.net.id

Nurhayati, KUSUMA g, Handayani N, Assadam A. 2014.Karakteristik buah naga putih (Hyclocereus undatus) dan buah naga merah (Hyclocereus

polyrhizuz).Prosiding Seminar Nasional Optimalisasi Potensi Hayati untuk mendukug Agroindustri Berkelanjutan. Universitas Truno-joyo. Bangkalan.18 Juni 2014.
Padmiarso W. 2012.Budidaya mentimun. Pustaka Agro. Jakarta

Panjuantiningrum, Feranose. 2009. Pengaruh Pemberian Buah Naga Merah(Hyclocereus polyrhizuz) Terhadap Kadar Glukosa darah Tikus putih yang diinduksi Aloksan. Skripsi ,Universitas Sebelas Maret.

Pramita, Y. 2003. Membongkar manfaat makanan berbuka puasa.TPG Puskesmas. Bandung,(online). (http://wikipedia.org.

Purnawan, W. 2010. Buah Naga. http://buahnagamanis.blogspot.co $\underline{m}$.

Qory Hajrul, Fajriani, 2013, Penentuan Aktivitas Antioksidan Kulit Buah Naga Super Merah (Hylocereus Costaricensis) Dan Produk Olahanya Berupa Permen Jelly, Skripsi, Universitas Pendidikan Indonesia, Jakarta

Setyaningsih D, Apriyantono A, Sari M. P. 2010. Analisis sensori untuk Industri pangan dan Agro. Bogor. IPB PRESS.

Sidauruk, Mutiara Y. 2013. Studi pembuatan Selai campuran Dami Nangka(Artocarpus heterophyllus) dengan Belimbing wuluh (Averrhoa billimbi L). Jurnal Teknologi Pangan Hal. 1-5 No. 1. Vol. 1. Yogyakarta.

Standar Nasional Indonesia (SNI). 2008. Selai. SNI 01-3746-1995.

Sulardjo, Santoso A. 2012. Pengaruh Konsentrasi Gula Pasir Terhadap Kualitas Jelli Buah Rambutan. Fakultas Teknologi Hasil Pertanian. UNWIDHA Klaten.

Thahjadi, Carmencita. (2008). Teknologi pengolahan sayur dan buah.Volume 2. Widya Padjadjaran: jatinangor.

Yulistiani, R., Murtiningsih, dan Munifa, M. 2009.Peran pectin dan sukrosa 
pada Selai Ubi Jalar Ungu (The Role of pectin and Sucrosa on purple sweet potato jam). Surabaya: UPN.

Wahyuni, Retna. 2009. Pemanfaatan kuliat buah Naga Super Merah (Hylicius Cestaricebsus) sebagai sumber Antioksidan dan pewarna Alami pada pembuatan jelly. Fakultas pertanian. Universitas Yudharta Pasuruan. Junal

Wahyuni, Rekna. 2012. Pemanfaatan Buah Naga Super Merah (Hylicius Cestaricebsus) Dalam pembuatan Jenang Dengan Perlakuan Penambahan Daging Buah yang berbeda. Jurnal Teknologi Pangan. Vol.4 No. 1.
Winaro F. G. 1992. Kimia pangan dan Gii.Jakarta : PT. Gramedia pustaka Winaro F. G. 1997. Pengantar Teknologi Pangan.Jakarta : PT. Gramedia pustaka

Winaro F. G. 2002. Kimia pangan dan Gii.Jakarta : PT. Gramedia pustaka Winaro F. G. 2004. Kimia pangan dan Gii.Jakarta : PT. Gramedia pustaka Wichienchot S, jatupornpipat M, Rastall RA. 2010. Oligosaccharides of pitaya (dragon fruit) flesh and their prebiotic properties. Food Chem 120:850-857. DOI 10.1016/j.foodchem.2009.11.026.

Zulkarnain, 2013.Budidaya sayuran Tropis. Bumi Aksara. Jakarta. 